\title{
PENGARUH TERAPI BEKAM TERHADAP PENURUNAN TEKANAN DARAH PADA PENDERITA HIPERTENSI DI PONDOK PENGOBATAN ALTERNATIF MIFTAHUSYIFA KOTA BENGKULU
}

\author{
Sardaniah $^{1)}$, Hj.Nurhasanah,SKM,M.Kes ${ }^{2)}$, Ns.Feny \\ Marlena,S.Kep,M.Kep ${ }^{3)}$ \\ 1) Dosen DIII Keperawatan Universitas Bengkulu, Dosen Bhakti \\ Husada Bengkulu ${ }^{2), 3)}$ Dosen Program studi Ilmu Keperawatan \\ Sekolah Tinggi (STIKes)Bhakti Husada Bengkulu.
}

\begin{abstract}
ABSTRAK
Latar Belakang Hipertensi adalah salah satu penyakit yang makin banyak dijumpai di Indonesia yang merupakan penyebab kematian ketiga untuk semua umur $(7,4 \%)$. Hipertensi adalah peningkatan tekanan darah yang melebihi tekanan darah normal, sistol lebih dari atau sama dengan $140 \mathrm{mmHg}$ dan tekanan diastol lebih dari atau sama dengan $90 \mathrm{mmHg}$. Penyakit ini merupakan faktor risiko yang besar untuk serangan jantung, stroke, dan gagal jantung. Tindakan pencegahan maupun penanganan sangat penting segera dilakukan untuk Menghindari peningkatan penyakit hiepertensi di Indonesia. Pengobatan hipertensi dapat dilakukan dengan pengobatan farmakologis, nonfarmakologis dan komplementer. Penyakit hipertensi harus segera ditangani, salah satunya dengan pengobatan komplementer yaitu bekam. Bekam merupakan suatu metode pengobatan penyakit dengan cara mengeluarkan angina atau darah kotor dari dalam tubuh melalui permukaan kulit.

Tujuan: penelitian ini adalah untuk mengetahui pengaruh terapi bekam terhadap tekanan darah pada pasien hipertensi.

Metode : Desain Penelitian yang digunakan pada penelitian ini adalah quasi experimental dengan one group pretest-posttest design. Jumlah sampel yang digunakan sebanyak 98 responden yang dilakukan di Pondok Pengobatan Alternatif Miftahusyifa Kota Bengkulu dengan melakukan 1 kali intervensi bekam.
\end{abstract}

Hasil uji statistik : ditemukan adanya perubahan pada tekanan darah yaitu terjadi penurunan dengan selisih nilai mean pada sistol $(12,143)$ dan diastol $(8,265)$. Uji statistik yang menggunakan uji skewness pada sistol dan diastol menunjukan nilai $(\mathrm{p}=0,000)$ yang berarti nilai $\mathrm{p}<0,05$ sehingga $\mathrm{H} 1$ diterima yang artinya menunjukan bahwa ada pengaruh yang signifikan terapi bekam terhadap perubahan tekan darah pada penderita hipertensi.

Saran peneliti : untuk penelitian selanjutnya manfaat terapi bekam untuk penyakit lainnya dan dijadikan tindakan keperawatan pengobatan komplementer untuk pasien hipertensi yang dapat digunakan masyarakat.

Kata Kunci : Terapi Bekam, Hipertensi 


\title{
THE EFFECT OF BEKAM THERAPY ON BLOOD PRESSURE REDUCTION \\ IN HYPERTENSION PATIENTS IN THE HOSPITAL ALTERNATIVE TREATMENT MIFTAHUSYIFA, BENGKULU CITY
}

\author{
Sardaniah1), Hj.Nurhasanah, SKM, M.Kes2), Ns.Feny Marlena, S.Kep, M.Kep3) \\ 1) Lecturer of Nursing DIII University of Bengkulu, Lecturer of Bhakti \\ Husada Bengkulu 2),Lecturer of Nursing Science Study Program (STIKes) \\ of Bhakti Husada3) Bengkulu.
}

\begin{abstract}
Background: Hypertension is a disease that is increasingly found in Indonesia, which is the third leading cause of death for all ages (7.4\%). Hypertension is an increase in blood pressure that exceeds normal blood pressure, systole more than or equal to $140 \mathrm{mmHg}$ and diastolic pressure more than or equal to $90 \mathrm{mmHg}$. This disease is a big risk factor for heart attack, stroke, and heart failure. Precautionary measures and treatment is very important to be done immediately to avoid the increase in hypertension in Indonesia. Treatment of hypertension can be done with pharmacological, non-pharmacological and complementary treatments. Hypertension must be treated immediately, one of them with complementary medicine is cupping. Cupping is a method of treating disease by removing dirty blood or blood from the body through the skin surface.

Objective: this study was to determine the effect of cupping therapy on blood pressure in hypertensive patients.

Method: The research design used in this study was a quasi experimental with one group pretest-posttest design. The number of samples used was 98 respondents conducted at the Miftahusyifa Alternative Medicine Pondok Bengkulu City by conducting a cupping intervention.
\end{abstract}

Statistical test results: found a change in blood pressure ie a decrease in the mean difference in systole $(12,143)$ and diastole $(8,265)$. Statistical tests using skewness tests on systole and diastole showed a value $(\mathrm{p}=0,000)$ which means a value of $p<0.05$ so that $\mathrm{H} 1$ was accepted which meant that there was a significant effect of cupping therapy on changes in blood pressure in patients with hypertension.

Researcher's suggestion: for further research the benefits of cupping therapy for other diseases and serve as a complementary treatment nursing treatment for hypertensive patients that can be used by the community.

Keywords: Cupping Therapy, Hypertension 


\section{A. PENDAHULUAN}

Wold Hearht organizatin (WHO) menunjukkan bahwa dari 57 juta kematian yang terjadi di dunia pada tahun 2008, sebanyak 36 juta atau hampir dua pertiganya disebabkan oleh Penyakit Tidak Menular (PTM) , Penyakit tidak menular menjadi penyebab utama kematian secara global. juga membunuh penduduk dengan usia yang lebih muda. Di negara-negara dengan tingkat ekonomi rendah dan menengah termasuk Indonesia, dari seluruh kematian yang terjadi pada orangorang berusia kurang dari 60 tahun, 29\% disebabkan oleh PTM, sedangkan di negara-negara maju, menyebabkan $13 \%$ kematian. Proporsi penyebab kematian PTM pada orang-orang berusia kurang dari 70 tahun, Prevalensi PTM akibat hipertensi meningkat dari 25, 8 persen menjadi 34,1persen (Riskesdas 2018)

Hipertensi adalah kondisi medis tekanan darah seseorang yang meningkat secara kronis (Susanto, 2010). Kemudian menurut Palmer (2007) mendefinisikan hipertensi sebagai tekanan sistolik lebih dari $140 \mathrm{mmHg}$ dan tekanan diastolik lebih dari $90 \mathrm{mmHg}$. Menurut Setiawan KemenKes (2015), bahwa hipertensi adalah suatu keadaan di mana seseorang mengalami peningkatan tekanan darah di atas normal yang mengakibatkan peningkatan angka kesakitan (mordibitas) dan angka kematian (mortalitas).

Menurut Aleyeidi N \& Kawthar A, (2015) Tekanan darah tinggi menjadi bermasalah hanya bila tekanan darah tersebut persisten karena membuat sistem sirkulasi dan organ yang mendapat suplai darah (termasuk jantung dan otak) menjadi tegangIrawan, $\mathrm{H}$ (2017), mengemukakan bahaya penyakit hipertensi itu sangat beragam. Apabila seseorang mengalami hipertensi maka dia juga akan mengalami komplikasi dengan penyakit lainnya. Hal ini terjadi karena terganggunya salah satu organ tubuh manusia akan menyebabkan gangguan pada organ lainnya. Apabila salah satu organ sakit maka organ yang lainnya akan ikut terganggu funngsinya. Komplikasi penyakit hipertensi itu diantaranya: gagal ginjal, merusak kinerja otak, merusak kinerja jantung, menyebabkan kerusakan mata, menyebabakan resintensi pembuluh darah, dan stroke.

Fenomena kejadian hipertensi menjadi perhatian dunia sehingga tanggal 17 Mei ditetapka nmenjadi hari hipertensi sedunia, angka prevalensi hipertensi yang didapatkan yaitu di Afrika (46\% dari orang dewasa) sedangkan prevalensi terendah di Amerika (35\% dari orang dewasa). Secara keseluruhan, negaranegara berpenghasilan tinggi memiliki prevalensi lebih rendah dari hipertensi (35\% dari orang dewasa) dari kelompok rendah dan middle penghasilan $(40 \%$ dari orang dewasa), prevalensi tekanan darah tinggi banyak di alami pada orang dewasa berusia 25 tahun keatas (WHO, 2013).

Penyakit hipertensi di Indonesia menjadi fenomena, berdasarkan hasil laporan perkembangan status kesehatan 
masyarakat Indonesia untuk tingkat nasional dan tingkat provinsi. Riset kesehatan dasar memperoleh hasil pada tahun 2013 yaitu Prevalensi hipertensi di Indonesia yang didapat melalui pengukuran pada umur $\geq 18$ tahun sebesar 25,8 persen, tertinggi di Bangka Belitung (30,9\%), diikuti Kalimantan Selatan (30,8\%), Kalimantan Timur $(29,6 \%)$ dan Jawa Barat (29,4\%).

Prevalensi hipertensi di Indonesia yang didapat melalui kuesioner terdiagnosis tenaga kesehatan sebesar 9,4 persen, yang didiagnosis tenaga kesehatan atau sedang minum obat sebesar 9,5 persen. Jadi, ada 0,1 persen yang minum obat sendiri. Responden yang mempunyai tekanan darah normal tetapi sedang minum obat hipertensi sebesar 0.7 persen. Jadi prevalensi hipertensi di Indonesia sebesar 26,5 persen $(25,8 \%+0,7$ \%) (Riskesdas, 2013).

Pencegahan hipertensi dapat dilakukan dengan pengobatan farmakologi, dan pengobatan komplementer. Pengobatan secara farmakologi dapat dilakukan dengan cara pemberian diuretiktiazide, penghambat adrenergik, angiotensin converting enzyme inhibitor (ACEinhibitor), angiotensin-II-blocker, antagonis kalsium, vasodilator. Pengobatan secara komplementer dapat dilakukan dengan cara terapi pijat, terapi refleksi, meditasi (Aboushanab,T.S 2018). Kemudian menurut Sharaf (2012), terapi bekam juga bisa digunakan untuk pengobatan penyakit hipertensi.

Terapi komplementer dikenal dengan terapi tradisional yang digabungkan dalam pengobatan modern, komplementer adalah penggunaan terapi tradisional kedalam pengobatan modern. Terapi komplementer ada dua, invasif dan non invasif.

Contoh terapi komplementer invasif seperti akupuntur dan cupping (Bekam) yang menggunakan jarum dalam pengobatannya. Kemudian contoh terapi komplementer non invasif seperti terapi energi (reiki, chikung, tai chi,prana, terapi suara) terapi biologis (herbal, terapi nutrisi, food combining, terapi jus, terapi urine, hidroterapi colon dan terapi sentuhan modalitas, akupreseur, pijat bayi, refleksi, rolfing dan terapi lainnya. Peran perawat yang dapat dilakukan dari pengetahuan tentang terapi komplementer diantaranya sebagai konselor, pendidik kesehatan, peneliti, pemberi pelayanan langsung, koordinator, dan sebagai advokat(Albedah,A dkk 2015).

Akhir-akhir ini banyak orang menyukai pengobatan komplementer, beberapa alasan diantaranya yaitu biaya terjangkau, tidak menggunakan bahan-bahan kimia dan efek penyembuhan cukup signifikan dan salah satu pengobatan komplementer yang dapat menangani hipertensi yaitu terapi bekam, (Umar, 2007). Di zaman Rasulullah Shallallahu'alaihi wa sallam bekam sudah banyak dikerjakan oleh para sahabat Radhiallahu'anhu. Bahkan menjadi sunnah dan kebiasaan mereka. Rasulullah shallallahu'alaihi wa sallam selain memerintahkanumatnya untuk berobat dengan bekam, juga memberikan petunjuk tentang 
tempat-tempat yang sangat baik untuk dibekam.

Bekam atau hijamah, secara bahasa berasal dari kata alhajmu yang artinya menghisap. Hajama asy-syai'a artinya mengisap sesuatu. Al-hajim dan alhajjam artinya yang menghisap. Karena itu, praktik pengisapan darah disebut al-hijamah sedangkan pelaku pengisapan disebut al-hajjam, (Sharaf, 2012)

Berdasarkan data pada klinik pengobatan alternatif Miftahusyifah dari tahun ketahun pasien yang terapi bekam mengalami peningkatan dengan berbagai diagnosa tahun 2016 sebanyak 3.850 orang, tahun 2017 sebanyak 4.110 Orang dan pada tahun 2018 sebanyak 4.800 orang melakukan terapi bekam, dari studi pendahuluan yang telah dilakukan peneliti dengan cara mewawancarai 16 orang pasien hipertensi yang melakukan bekam di Pondok Pengobatan alternatif Miftahusyifa Kota Bengkulu, 10 orang pasien mengatakan tekanan darah mengalami penurunan setelah berbekam dan 6 pasien mengatakan tidak ada perununan pada tekanan darahnya tetapi pasien mengatakan badan terasa nyaman dan ringan setelah dilakukan Bekam.

Berdasarkan latar belakang diatas peneliti tertarik untuk melakukan penelitian tentang pengaruh terapi bekam terhadap tekanan darah pada pasien hipertensi di Pondok Pengobatan alternatif Miftahusyifah tahun 2019.

\section{B. METODE PENELITIAN}

Penelitian ini merupakan penelitian kuantitatif, menggunakan quasi experimental design dengan one group pretest-posttest design.Penelitian ini dilakukan dengan cara memberikan pretest (pengamatan awal) terlebih dahulu sebelum diberikan intervensi, setelah itu diberikan intervensi, kemudian dilakukan kembali posttest (pengamatan akhir) (Saryono, 2011). Rancangan ini juga tidak ada kelompok pembanding (kontrol), tetapi paling tidak sudah dilakukan observasi pertama (pretest) yang memungkinkan menguji suatu perubahan- perubahan yang terjadi setelah terjadinya eksperimen (Notoatmodjo,2010).

\section{C.HASIL PENELITAN}

Penelitian ini dilaksanakan di Klinik Pengobatan alternatif Miftahusyifa Kota Bengkulu Tahun 2019 pada tanggal 23 Agustus sampai dengan 5 September 2019.

Penelitian ini menggunakan desain penelitian Quasi Exsperimental Design dengan pendekatan pretestpostest with Control Group Design Populasi dalam penelitian ini adalah seluruh pasien hipertensi sebanyak 4800 orang. Cara pengambilan sampel dalam penelitian ini diambil dengan menggunakan teknik Purposive Sampling. Sampel yang diambil adalah 98 orang yang mewakili seluruh pasien hipertensi di Klinik Pengobatan alternatif Miftahusyifa Kota Bengkulu Tahun 2019.

\section{Analisis Univariat}


Table 5.1 Distribusi frekuensi TD responden sebelum dan sesudah diberikan Terapi bekam

\begin{tabular}{|c|c|c|}
\hline 8istol Sebelum Bekam & Frekuensi & Persentase $(\%)$ \\
\hline \multirow{3}{*}{$\begin{array}{ll} & 150 \\
3 . & 160 \\
170\end{array}$} & 63 & 64.3 \\
\hline & 33 & 33,7 \\
\hline & 2 & 2 \\
\hline Sistol Sesudah Bekam & Frekuensi & Persentase $(\%)$ \\
\hline \multirow{3}{*}{$\begin{array}{ll} & 120 \\
5 . & 130 \\
140\end{array}$} & 42 & 42,9 \\
\hline & 42 & 42,9 \\
\hline & 14 & 14,3 \\
\hline $\begin{array}{l}6 . \\
\text { Diastol Sebelum Bekam }\end{array}$ & Frekuensi & Persentase $(\%)$ \\
\hline \multirow{3}{*}{$\begin{array}{lc}7 . & 90 \\
& 100 \\
110 \\
\end{array}$} & 59 & 60,2 \\
\hline & 9 & 9,2 \\
\hline & 30 & 30.6 \\
\hline Diastol Sesudah Bekam & Frekuensi & Persentase $(\%)$ \\
\hline 80 & 84 & 85,7 \\
\hline 90 & 14 & 14,3 \\
\hline Jumlah & 98 & 100 \\
\hline
\end{tabular}

\section{Analisis Bivariat}

Analisis ini dilakukan untuk mengetahui pengaruh tekanan darah

pasien hipertensi sebelum dan sesudah dilakukan terapi bekam

hasil uji normalitas data dengan satu skala ukur dapat dilihat pada tabel dibawah ini :

Tabel 5.2 Hasil Uji Normalitas Data

\begin{tabular}{lccc}
\hline \multicolumn{1}{c}{ Bekam } & \multicolumn{3}{c}{ Shapiro-Wilk } \\
\hline Statistic & Statistic & Df & Sig. \\
\hline Sistol Sebelum & 0.409 & 98 & 0.000 \\
\hline Sistol Sesudah & 0.270 & 98 & 0.000 \\
\hline Diastol Sebelum & 0.385 & 98 & 0.000 \\
\hline Diastol Sesudah & 0,514 & 98 & 0.000 \\
\hline
\end{tabular}


Berdasarkan tabel 5.2 menunjukkan bahwa hasil uji normalitas data dengan satu skala ukur dapat dilakukan intervensi bekam diperoleh nilai $\rho=0,000$ dan sesudah dilakukan intervensi diperoleh nilai $\rho=0,000$. Kedua nilai $\rho$ tersebut lebih kecil dari nilai $\alpha=0,05(\rho<\alpha)$ yang berarti keduanya mempunyai data yang terdistribusi tidak normal. Dengan demikian, uji normalitas ini tidak memenuhi syarat untuk dijelaskan sebagai berikut: Dengan alat ukur sebelum

dilakukan uji Independent samples $t$ test sehingga menggunakan uji $T$ seperti terlihat pada tabel berikut:

Tabel 5.3 Pengaruh Terapi Bekam terhadap penurunan tekanan darah pada pasien Hipertensi di Klinik Pengobatan alternatif Miftahusyifa Kota Bengkulu

\begin{tabular}{cccc}
\hline Variabel & Mean & STD & P \\
\hline Sistol Sebelum & 154 & 5.279 & 0,000 \\
\hline Sistol Sesudah & 127 & 7.035 & 0,000 \\
\hline Diastol Sebelum & 97 & 9.055 & 0,000 \\
\hline Diastol Sesudah & 81 & 3.517 & 0,000 \\
\hline
\end{tabular}

Dari tabel 5.3 Pengaruh Terapi Bekam terhadap penurunan tekanan darah pada pasien Hipertensi di pondok Pengobatan alternatif Miftahusyifa Kota Bengkulu digunakan uji $\mathrm{T}$ didapat nilai ratarata tekanan darah sebelum dilakukan bekam 154/96 mmHg dan setelah dilakukan bekam didapat nilai rata-rata tekanan darah 127/81 dengan nilai asymp.sig (p) $=0,000$. Karena nilai $\alpha<0,05$ berarti ada perbedaan yang signifikan, maka Ho ditolak dan Ha diterima. Artinya ada
Pengaruh Terapi Bekam terhadap penurunan tekanan darah pada pasien Hipertensi di Klinik Pengobatan alternatif Miftahusyifa Kota Bengkulu. 
Tabel 5.3 Pengaruh Terapi Bekam terhadap penurunan tekanan darah pada pasien Hipertensi di Klinik Pengobatan alternatif Miftahusyifa Kota Bengkulu

\begin{tabular}{cccc}
\hline Variabel & Mean & STD & P \\
\hline Sistol Sebelum & 154 & 5.279 & 0,000 \\
\hline Sistol Sesudah & 127 & 7.035 & 0,000 \\
\hline Diastol Sebelum & 97 & 9.055 & 0,000 \\
\hline Diastol Sesudah & 81 & 3.517 & 0,000 \\
\hline
\end{tabular}

Dari tabel 5.3 Pengaruh Terapi Bekam terhadap penurunan tekanan darah pada pasien Hipertensi di pondok Pengobatan alternatif Miftahusyifa Kota Bengkulu digunakan uji $\mathrm{T}$ didapat nilai ratarata tekanan darah sebelum dilakukan bekam 154/96 mmHg dan setelah dilakukan bekam didapat nilai rata-rata tekanan darah $127 / 81$ dengan nilai asymp.sig (p) $=0,000$. Karena nilai $\alpha<0,05$ berarti ada perbedaan yang signifikan, maka Ho ditolak dan Ha diterima. Artinya ada Pengaruh Terapi Bekam terhadap penurunan tekanan darah pada pasien Hipertensi di Klinik Pengobatan alternatif Miftahusyifa Kota Bengkulu.

\section{D.PEMBAHASAN}

Pengaruh Terapi Bekam terhadap penurunan tekanan darah pada pasien Hipertensi di Pondok Pengobatan alternatif Miftahusyifa Kota Bengkulu.

Pada penelitian uji statistic yang digunakan untuk mengetahui perbedaan tekanan darah sebelum dan sesudah dilakukan terapi bekam adalah Uji T. Didapat nilai rata-rata tekanan darah sebelum dilakukan bekam 154/96 mmHg dan setelah dilakukan bekam didapat nilai ratarata tekanan darah 127/81 dengan nilai $\mathrm{z} \quad-8419$ dan didapat nilai $\operatorname{asymp.sig}(\mathrm{p})=0,000$. Karena nilai $\alpha<0,05$ berarti ada perbedaan yang signifikan, maka Ho ditolak dan $\mathrm{Ha}$ diterima. Artinya ada Pengaruh Terapi Bekam terhadap penurunan tekanan darah pada pasien Hipertensi di Klinik Pengobatan alternatif Miftahusyifa Kota Bengkulu..

Suatu penelitian dilakukan membuktikan bahwa apabila pembekaman pada satu poin maka kulit (kutis), jaringan bawah kulit(subkutis), fasia dan otot akan terjadi kerusakan dari mast cell atau lain-lain. Akibat kerusakan ini akan dilepaskan beberapa zat seperti serotonin, histamine, bradikinin, slowreaching substance (SRS) serta zat lain yang belum diketahui. Zatzat ini menyebabkan terjadinya pelebaran kapiler dan arteriol serta flare reaction pada daerah yang dibekam.

Dilatasi kapiler juga dapat terjadi ditempat yang jauh dari tempat pembekaman ini 
menyebabkan terjadinya perbaikan mikrosirkulasi pembuluh darah. Akibatnya timbul efek relaksasi (pelemasan) otot-otot yang kaku serta akibat vasodilatasi umum akan menurunkan tekanan darah secara stabil (Kusyati, 2012).

Mekanisme penyembuhan bekam pada hipertensi didasarkan atas teori aktivasi organ, dimana bekam akan mengaktivasi organ yang mengatur aliran darah seperti hati, ginjal dan jantung agar organorgan ini tetap aktif dalam mengatur peredaran darah sehingga tekanan darah tetap terjaga. Selain itu bekam juga berusaha menyeimbangkan secara alamiah bila ada tekanan darah yang meningkat.Dengan memilih titik yang tepat, maka bekam bisa membantu penanganan hipertensi (Umar,2008).

Bekam yang sudah dipakai di masyarakat sejak ribuan tahun lalu juga sering dipakai untuk menangani hipertensi.Secara khusus, pembekaman pada titik yang tepat dapat menurunkan tekanan darah dengan segera (Umar, 2008). Efek terapi bekam terhadap hipertensi diantaranya: bekam berperan menenangkan sistem saraf simpatik (simpatic nervous system). Pergolakan pada sistem saraf simpatik ini menstimulasi sekresi enzim yang berperan sebagai sistem angiotensinennin. Setelah sistem ini tenang dan aktivitasnya berkurang tekanan darah akan turun. Bekam berperan menurunkan volume darah yang mengalir di pembuluh darah sehingga mengurangi tekanan darah (Sharaf, 2012)

Bekam mengendalikan tekanan
hormone aldosterone sehingga
mengendalikan tekanan darah.

Bekam berperan menstimulasi reseptor-reseptor khusus yang terkait dengan penciutan dan peregangan pembuluh darah (Baroreseptor) sehingga pembuluh darah bisa merespon berbagai stimulus dan meningkatkan kepekaannya terhadap faktor-faktor penyebab hipertensi (Sharaf,2010).

Dengan berbekam terjadi perangsangan pada regulator kardiovaskuler terutama pada tahanan peripheral (peripheral resistance). Melalui efek-efek yang terjadi akibat bekam. Menurut Sharaf (2012) Efek bekam terhadap hipertensi adalah berperan menenangkan sistem saraf simpatik (simpatic nerveous system). Pergolakan pada sistem saraf simpatik ini menstimulasi sekresi enzim yang berperan sebagai sistem angiotensin renin. Setelah sistem ini tenang dan aktivitasnya berkurang tekanan darah akan turun;

Bekam juga mengendalikan kadar hormon aldosteron; Zat nitrat oksida (NO) yang berperan dalam vasodilatasi, melalui zat nitrat oksida ini juga berperan meningkatkan suplai nitrisi dan darah yang dibutuhkan oleh sel-sel dan lapisanlapisan pembuluh darah arteri maupun vena, sehingga pembuluh darah menjadi lebih kuat dan elastis. Serta bekam berperan menstimulasi reseptor-reseptor (baroreseptor) sehingga pembuluh darah bisa merespon stimulus dan meningkatkan kepekaannya terhadap faktor-faktor penyebab hipertensi (Sharaf 2012).

Selain itu, efek pembekaman pada satu titik, maka di jaringan 
kulit (kutis), jaringan bawah kulit (Sub kutis), fascia dan ototnya akan terjadi kerusakan dari Mast Cell, yang akibatnya melepaskan beberapa mediator kimia sehingga terjadi dilatasi kapiler dan arteriol. Dilatasi kapiler dan arteriol ini menyebabkan terjadinya perbaikan mikrosirkulasi pembuluh darah dan timbul efek relaksasi otot-otot yang kaku, serta akibat vasodilatasi umum akan menurunkan tekanan darah secara stabil. Yang terpenting adalah dilepaskannya Kortikotropin Releasing Factor (CRF) serta releasing faktor lainnya oleh adenohipofise. CRF selanjutnya akan menyebabkan terbentuknya ACTH, kortikotropin, dan kortikosteroid. Kortikosteroid ini mempunyai efek menyembuhkan peradangan serta menstabilkan permeabilitas sel.

Penelitian lainnya menunjukkan bahwa pembekaman dikulit akan menstimulasi kuat syaraf permukaan kulit yang akan dilanjutkan pada cornu posterior medulla spinalis melalui syaraf A-delta dan C, serta traktus spino thalamicus kearah thalamus yang akan menghasilkan endorphin. Sedangkan sebagian rangsangan lainnya akan diteruskan melalui serabut aferen simpatik menuju ke motor neuron dan menimbulkan reflek intubasi nyeri. Efek lainnya adalah dilatasi pembuluh darah kulit, dan peningkatan kerja jantung (Umar, 2008).

Penelitian sebelumya dilakukan oleh Alfian, (2016) tentang " Pengaruh terapi Bekam terhadap tekanan darah pada pasien Hipertensi di Klinik Bekam Abu Zaky Mubarak Bogor. Penelitian quasi experimental dengan one group pretest-posttest design. Jumlah sampel yang digunakan sebanyak 25 responden dengan melakukan 1 kali intervensi bekam. Hasil uji statistik ditemukan adanya perubahan pada tekanan darah yaitu terjadi penurunan dengan selisih nilai mean pada sistol $(15,60)$ dan diastol $(9,40)$. Uji statistik yang menggunakan uji Wilcoxon pada sistol dan diastol menunjukan nilai $(\mathrm{p}=0,000)$ yang berarti nilai $\mathrm{p}<0,05$ menunjukan bahwa ada pengaruh yang signifikan terapi bekam terhadap perubahan tekan darah pada pasien hipertensi.

Pada penelitian uji statistic yang digunakan untuk mengetahui perbedaan tekanan darah sebelum dan sesudah dilakukan terapi bekam adalah Uji T. Didapat nilai rata-rata tekanan darah sebelum dilakukan bekam 154/96 $\mathrm{mmHg}$ dan setelah dilakukan bekam didapat nilai rata-rata tekanan darah 127/81 dengan nilai $\mathrm{z}-8419$ dan didapat nilai asymp.sig (p) $=0,000$. Karena nilai $\alpha<0,05$ berarti ada perbedaan yang signifikan, maka Ho ditolak dan $\mathrm{Ha}$ diterima. Artinya ada Pengaruh Terapi Bekam terhadap penurunan tekanan darah pada pasien Hipertensi di Klinik Pengobatan alternatif Miftahusyifa Kota Bengkulu..

Suatu penelitian dilakukan membuktikan bahwa apabila pembekaman pada satu poin maka kulit (kutis), jaringan bawah kulit(subkutis), fasia dan otot akan terjadi kerusakan dari mast cell atau lain-lain. Akibat kerusakan ini akan dilepaskan beberapa zat seperti serotonin, histamine, bradikinin, slowreaching substance (SRS) serta 
zat lain yang belum diketahui. Zat-zat ini menyebabkan terjadinya pelebaran kapiler dan arteriol serta flare reaction pada daerah yang dibekam.

Dilatasi kapiler juga dapat terjadi ditempat yang jauh dari tempat pembekaman ini menyebabkan terjadinya perbaikan mikrosirkulasi pembuluh darah. Akibatnya timbul efek relaksasi (pelemasan) otot-otot yang kaku serta akibat vasodilatasi umum akan menurunkan tekanan darah secara stabil (Kusyati, 2012).

Mekanisme penyembuhan bekam pada hipertensi didasarkan atas teori aktivasi organ, dimana bekam akan mengaktivasi organ yang mengatur aliran darah seperti hati, ginjal dan jantung agar organorgan ini tetap aktif dalam mengatur peredaran darah sehingga tekanan darah tetap terjaga. Selain itu bekam juga berusaha menyeimbangkan secara alamiah bila ada tekanan darah yang meningkat.Dengan memilih titik yang tepat, maka bekam bisa membantu penanganan hipertensi (Umar,2008).

Bekam yang sudah dipakai di masyarakat sejak ribuan tahun lalu juga sering dipakai untuk menangani hipertensi.Secara khusus, pembekaman pada titik yang tepat dapat menurunkan tekanan darah dengan segera (Umar, 2008). Efek terapi bekam terhadap hipertensi diantaranya: bekam berperan menenangkan sistem saraf simpatik (simpatic nervous system). Pergolakan pada sistem saraf simpatik ini menstimulasi sekresi enzim yang berperan sebagai sistem angiotensinennin. Setelah sistem ini tenang dan aktivitasnya berkurang tekanan darah akan turun. Bekam berperan menurunkan volume darah yang mengalir di pembuluh darah sehingga mengurangi tekanan darah (Sharaf, 2012)

Bekam mengendalikan tekanan hormone aldosterone sehingga mengendalikan tekanan darah. Bekam berperan menstimulasi reseptor-reseptor khusus yang terkait dengan penciutan dan peregangan pembuluh darah (Baroreseptor) sehingga pembuluh darah bisa merespon berbagai stimulus dan meningkatkan kepekaannya terhadap faktor-faktor penyebab hipertensi (Sharaf,2010).

Dengan berbekam terjadi perangsangan pada regulator kardiovaskuler terutama pada tahanan peripheral (peripheral resistance). Melalui efek-efek yang terjadi akibat bekam. Menurut Sharaf (2012) Efek bekam terhadap hipertensi adalah berperan menenangkan sistem saraf simpatik (simpatic nerveous system). Pergolakan pada sistem saraf simpatik ini menstimulasi sekresi enzim yang berperan sebagai sistem angiotensin renin. Setelah sistem ini tenang dan aktivitasnya berkurang tekanan darah akan turun;

Bekam juga mengendalikan kadar hormon aldosteron; Zat nitrat oksida (NO) yang berperan dalam vasodilatasi, melalui zat nitrat oksida ini juga berperan meningkatkan suplai nitrisi dan darah yang dibutuhkan oleh sel-sel dan lapisanlapisan pembuluh darah arteri maupun vena, sehingga pembuluh darah menjadi lebih kuat dan elastis. Serta bekam berperan menstimulasi reseptor-reseptor (baroreseptor) sehingga pembuluh darah bisa merespon stimulus dan 
meningkatkan kepekaannya terhadap faktor-faktor penyebab hipertensi (Sharaf 2012).

Selain itu, efek pembekaman pada satu titik, maka di jaringan kulit (kutis), jaringan bawah kulit (Sub kutis), fascia dan ototnya akan terjadi kerusakan dari Mast Cell, yang akibatnya melepaskan beberapa mediator kimia sehingga terjadi dilatasi kapiler dan arteriol. Dilatasi kapiler dan arteriol ini menyebabkan terjadinya perbaikan mikrosirkulasi pembuluh darah dan timbul efek relaksasi otot-otot yang kaku, serta akibat vasodilatasi umum akan menurunkan tekanan darah secara stabil. Yang terpenting adalah dilepaskannya Kortikotropin Releasing Factor (CRF) serta releasing faktor lainnya oleh adenohipofise. CRF selanjutnya akan menyebabkan terbentuknya ACTH, kortikotropin, dan kortikosteroid. Kortikosteroid ini mempunyai efek menyembuhkan peradangan serta menstabilkan permeabilitas sel.

Penelitian

lainnya menunjukkan bahwa pembekaman dikulit akan menstimulasi kuat syaraf permukaan kulit yang akan dilanjutkan pada cornu posterior medulla spinalis melalui syaraf A-

Dengan alat ukur sebelum dilakukan intervensi bekam diperoleh nilai $\rho=0,000$ dan sesudah dilakukan intervensi diperoleh nilai $\rho=0,000$. Kedua nilai $\rho$ tersebut lebih kecil dari nilai $\alpha=0,05(\rho<\alpha)$ yang berarti keduanya mempunyai data yang terdistribusi tidak normal. Dengan demikian, uji normalitas ini tidak memenuhi syarat untuk dilakukan uji Independent samples $t$ test sehingga menggunakan uji $T$ seperti digunakan uji $\mathrm{T}$ didapat nilai delta dan C, serta traktus spino thalamicus kearah thalamus yang akan menghasilkan endorphin. Sedangkan sebagian rangsangan lainnya akan diteruskan melalui serabut aferen simpatik menuju ke motor neuron dan menimbulkan reflek intubasi nyeri. Efek lainnya adalah dilatasi pembuluh darah kulit, dan peningkatan kerja jantung (Umar, 2008).

Penelitian sebelumya dilakukan oleh Alfian, (2016) tentang "Pengaruh terapi Bekam terhadap tekanan darah pada pasien Hipertensi di Klinik Bekam Abu Zaky Mubarak Bogor. Penelitian quasi experimental dengan one group pretest-posttest design. Jumlah sampel yang digunakan sebanyak 25 responden dengan melakukan 1 kali intervensi bekam. Hasil uji statistik ditemukan adanya perubahan pada tekanan darah yaitu terjadi penurunan dengan selisih nilai mean pada sistol $(15,60)$ dan diastol $(9,40)$. Uji statistik yang menggunakan uji Wilcoxon pada sistol dan diastol menunjukan nilai $(\mathrm{p}=0,000)$ yang berarti nilai $\mathrm{p}<0,05$ menunjukan bahwa ada pengaruh yang signifikan terapi bekam terhadap perubahan tekan darah pada pasien hipertensi. rata-rata tekanan darah sebelum dilakukan bekam 154/96 mmHg dan setelah dilakukan bekam didapat nilai rata-rata tekanan darah 127/81 dengan nilai asymp.sig (p) $=0,000$. Karena nilai $\alpha<0,05$ berarti ada perbedaan yang signifikan, maka Ho ditolak dan Ha diterima. Artinya ada Pengaruh Terapi Bekam terhadap penurunan tekanan darah pada pasien Hipertensi di Klinik Pengobatan alternatif Miftahusyifa Kota Bengkulu. 


\section{D.Pembahasan}

Pada penelitian uji statistic yang digunakan untuk mengetahui perbedaan tekanan darah sebelum dan sesudah dilakukan terapi bekam adalah Uji T. Didapat nilai rata-rata tekanan darah sebelum dilakukan bekam 154/96 mmHg dan setelah dilakukan bekam didapat nilai ratarata tekanan darah 127/81 dengan nilai $\mathrm{z} \quad-8419$ dan didapat nilai asymp.sig $(\mathrm{p})=0,000$. Karena nilai $\alpha<0,05$ berarti ada perbedaan yang signifikan, maka Ho ditolak dan $\mathrm{Ha}$ diterima. Artinya ada Pengaruh Terapi Bekam terhadap penurunan tekanan darah pada pasien Hipertensi di Klinik Pengobatan alternatif Miftahusyifa Kota Bengkulu..

Suatu penelitian dilakukan membuktikan bahwa apabila pembekaman pada satu poin maka kulit (kutis), jaringan bawah kulit(subkutis), fasia dan otot akan terjadi kerusakan dari mast cell atau lain-lain. Akibat kerusakan ini akan dilepaskan beberapa zat seperti serotonin, histamine, bradikinin, slowreaching substance (SRS) serta zat lain yang belum diketahui. Zatzat ini menyebabkan terjadinya pelebaran kapiler dan arteriol serta flare reaction pada daerah yang dibekam.

Dilatasi kapiler juga dapat terjadi ditempat yang jauh dari tempat pembekaman ini menyebabkan terjadinya perbaikan mikrosirkulasi pembuluh darah. Akibatnya timbul efek relaksasi (pelemasan) otot-otot yang kaku serta akibat vasodilatasi umum akan menurunkan tekanan darah secara stabil (Kusyati, 2012).

Mekanisme penyembuhan bekam pada hipertensi didasarkan atas teori aktivasi organ, dimana bekam akan mengaktivasi organ yang mengatur aliran darah seperti hati, ginjal dan jantung agar organorgan ini tetap aktif dalam mengatur peredaran darah sehingga tekanan darah tetap terjaga. Selain itu bekam juga berusaha menyeimbangkan secara alamiah bila ada tekanan darah yang meningkat.Dengan memilih titik yang tepat, maka bekam bisa membantu penanganan hipertensi (Umar,2008).

Bekam yang sudah dipakai di masyarakat sejak ribuan tahun lalu juga sering dipakai untuk menangani hipertensi.Secara khusus, pembekaman pada titik yang tepat dapat menurunkan tekanan darah dengan segera (Umar, 2008). Efek terapi bekam terhadap hipertensi diantaranya: bekam berperan menenangkan sistem saraf simpatik (simpatic nervous system). Pergolakan pada sistem saraf simpatik ini menstimulasi sekresi enzim yang berperan sebagai sistem angiotensinennin. Setelah sistem ini tenang dan aktivitasnya berkurang tekanan darah akan turun. Bekam berperan menurunkan volume darah yang mengalir di pembuluh darah sehingga mengurangi tekanan darah (Sharaf, 2012)

Bekam mengendalikan tekanan hormone aldosterone sehingga mengendalikan tekanan darah. Bekam berperan menstimulasi reseptor-reseptor khusus yang terkait dengan penciutan dan peregangan pembuluh darah (Baroreseptor) sehingga pembuluh darah bisa merespon berbagai stimulus dan meningkatkan kepekaannya terhadap faktor-faktor penyebab hipertensi (Sharaf,2010). 
$\begin{array}{ccc}\text { Dengan } & \text { berbekam } & \text { terjadi } \\ \text { perangsangan } & \text { pada regulator }\end{array}$ kardiovaskuler terutama pada tahanan peripheral (peripheral resistance). Melalui efek-efek yang terjadi akibat bekam. Menurut Sharaf (2012) Efek bekam terhadap hipertensi adalah berperan menenangkan sistem saraf simpatik (simpatic nerveous system). Pergolakan pada sistem saraf simpatik ini menstimulasi sekresi enzim yang berperan sebagai sistem angiotensin renin. Setelah sistem ini tenang dan aktivitasnya berkurang tekanan darah akan turun;

Bekam juga mengendalikan kadar hormon aldosteron; Zat nitrat oksida (NO) yang berperan dalam vasodilatasi, melalui zat nitrat oksida ini juga berperan meningkatkan suplai nitrisi dan darah yang dibutuhkan oleh selsel dan lapisan-lapisan pembuluh darah arteri maupun vena, sehingga pembuluh darah menjadi lebih kuat dan elastis. Serta bekam berperan menstimulasi reseptor-reseptor (baroreseptor) sehingga pembuluh darah bisa merespon stimulus dan meningkatkan kepekaannya terhadap faktor-faktor penyebab hipertensi (Sharaf 2012).

Selain itu, efek pembekaman pada satu titik, maka di jaringan kulit (kutis), jaringan bawah kulit (Sub kutis), fascia dan ototnya akan terjadi kerusakan dari Mast Cell, yang akibatnya melepaskan beberapa mediator kimia sehingga terjadi dilatasi kapiler dan arteriol. Dilatasi kapiler dan arteriol ini menyebabkan terjadinya perbaikan mikrosirkulasi pembuluh darah dan timbul efek relaksasi otot-otot yang kaku, serta akibat vasodilatasi umum akan menurunkan tekanan darah secara stabil. Yang terpenting adalah dilepaskannya Kortikotropin Releasing Factor (CRF) serta releasing faktor lainnya oleh adenohipofise. CRF selanjutnya akan menyebabkan terbentuknya ACTH, kortikotropin, dan kortikosteroid. Kortikosteroid ini mempunyai efek menyembuhkan peradangan serta menstabilkan permeabilitas sel.

Penelitian lainnya menunjukkan bahwa pembekaman dikulit akan menstimulasi kuat syaraf permukaan kulit yang akan dilanjutkan pada cornu posterior medulla spinalis melalui syaraf A-delta dan C, serta traktus spino thalamicus kearah thalamus yang akan menghasilkan endorphin. Sedangkan sebagian rangsangan lainnya akan diteruskan melalui serabut aferen simpatik menuju ke motor neuron dan menimbulkan reflek intubasi nyeri. Efek lainnya adalah dilatasi pembuluh darah kulit, dan peningkatan kerja jantung (Umar, 2008).

Penelitian sebelumya dilakukan oleh Alfian, (2016) tentang " Pengaruh terapi Bekam terhadap tekanan darah pada pasien Hipertensi di Klinik Bekam Abu Zaky Mubarak Bogor. Penelitian quasi experimental dengan one group pretest-posttest design. Jumlah sampel yang digunakan sebanyak 25 responden dengan melakukan 1 kali intervensi bekam. Hasil uji statistik ditemukan adanya perubahan pada tekanan darah yaitu terjadi penurunan dengan selisih nilai mean pada sistol $(15,60)$ dan diastol $(9,40)$. Uji statistik yang menggunakan uji Wilcoxon pada sistol dan diastol menunjukan nilai $(\mathrm{p}=0,000)$ yang berarti nilai $\mathrm{p}<0,05$ 
menunjukan bahwa ada pengaruh yang signifikan terapi bekam hipertensi.

\section{DAFTAR PUSTAKA}

Akbar,Noor \& Mahati.Pengaruh Bekam Basah terhadap Kolestrol dan tekanan darah pada pasien Hipertensi DI Semarang 2013

Aleyeidi,Nouran et al. The efficacy of wet cupping on bloog Pressure among hypertension Patiens in Jeddah, Saudi Arabia: A Randomized controlled Trial Pilot Study. Integ Med : Saudi Arabia: 2014

A.Ali Ridho Bekam Sinergi Rahasia Sinergi Pengobatan Nabi, Medis Modern \& Tradisional Chinese Medicine,PT.Aqwam Media Profetika Kartasura SOLO 2017

Arikunto, Suharsimi. Manajemen Penelitian.PT. Rineka Cipta: Jakarta 2010.

A.R.Syaraf .Penyakit dan Terapi Bekamnya, Dasar-dasar Ilmiah terapi Bekam. Surakarta 2012

Depkes RI. Profil Kesehatan Indonesia, Departemen Kesehatan Republik Indonesia 2018

Fera. Pengaruh terapi bekam terhadap tekanan darah pada pasien hipertensi di klinik Bekam De Besh Centre Arrahman dan Rumah Sakit Sabbihisama Kota Padang, Jurnal Keperawatan Universitas andalas: Padang 2012 terhadap perubahan tekan darah pada pasien

Hasmi,Lajnah Ilmiah. Warisan Nabi dalam Pengobatan: Mengungkapkan keajaiban Metode Bekam dan Habbatus Sauda. LBKI: Bogor 2012

Kusyati, Eni dkk. Pengaruh arah Putaran jarum Bekam basah terhadap Tekanan Darah Penderita Hipertensi di Kedung Mundu Semarang. PPNI Jawa Tengah: Semarang 2014

Kusyati,E. Bekam sebagai Terapi komplementer.Popup Design: Yogyakarta. 2012.

Notoatmodjo,soekidjo. Imu Perilaku Kesehatan. Renika Cipta: Jakarta.2010.

Notoatmodjo ,soekidjo. Metodologi Penelitian Kesehatan. Rineka Cipta: Jakarta 2010

Rahman. Pengaruh terapi Bekam Terhadap penurunan tekanan darah pada pasien Hipertensi di Klinik Abu Zaky Bogor tahun 2016

Santoso,Ody. Pelatihan Bekam atau Hijamah. Yayasan Amal Media Suara Islam: Jakarta 2012

Saryono Penurunan Kadar Kolestrol Total pada pasien Hipertensi yang mendapat Terapi Bekam di Klinik An-Nahl Purwokerto. Jurnal Keperawatan Soedirman : Purwokerto 2010. 


